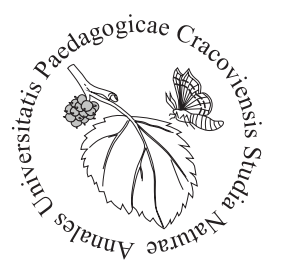

Lívia Handrová*, Anna Čuvalová, Vladimír Kmet Institute of Animal Physiology, Centre of Biosciences of the SAS, Soltesovej 4/6, 04001 Kosice, Slovak Republic, ${ }^{\star}$ handrova@saske.sk

\title{
The relationship between biofilm formation, genes of virulence and iron metabolism in Escherichia coli
}

\section{Introduction}

Urinary tract infections (UTIs) are the most prevalent infectious diseases, and very problematic worldwide (Navidinia et al., 2018). Uropathogenic Escherichia coli T. Escher. (UPEC), which can colonise successfully in the urinary tract, is the primary etiologic agents associated with UTI (Peerayeh et al., 2018). Avian pathogenic E. coli (APEC) cause septicemia, polyserositis, aerosacculitis and other mainly extraintestinal diseases in chickens and other avian species. APECs are found in the intestinal microbiota of healthy birds, and most of the diseases associated with them are secondary to environmental and host predisposing factors (Dho-Moulin, Fairbrother, 1999). The common presence of a set of virulence-associated genes among as well as similar disease patterns and phylogenetic background indicate a genetic relationship between APEC and UPEC isolates (Kaper et al., 2004; Moulin-Schouleur et al., 2006; Ron, 2006). The success of E. coli in colonising such a wide range of hosts and environments is basically due to a noticeable ductility in exploiting the available resources. It is becoming increasingly clear that biofilms have an enormous impact on medicine (Mah, O'Toole, 2001; Wang et al., 2017), since 65\% of human microbial infections involve biofilms (Labbate et al., 2004). Microbial biofilm formation is now recognised as a principle virulence factor in many localised chronic infections (Hyun Koo et al., 2017), and their role in infecting the biological devices among hospitalised patients is a universally accepted fact (Vasudevan, 2014). In addition, recent experimental evidence indicates a role of biofilm formation in acute infections (Hannan et al., 2012; Kumagai et al., 2011). Understanding biofilm formation to find effective ways to prevent biofilms is important for combating disease.

The primary aim of this study was to detect $E$. coli strains with a biofilm formation from animals and the detection of APEC virulence genes presence in these strains in compared to the ability of production a biofilm. 
Escherichia coli strains were isolated from broilers rectal swab coming from farms of Eastern Slovakia. Samples were resuscitated overnight at $37^{\circ} \mathrm{C}$ in buffered peptone water (Oxoid, Basingstoke, UK) and subcultured on Mac Conkey agar (Oxoid) and UriSelect agar (Bio-Rad Laboratories, Hercules, CA, USA) again overnight at $37^{\circ} \mathrm{C}$. The colonies were isolated, identified, and confirmed as E. coli by commercial identification microsystem ENTEROtest24 (ErbaLachema Brno, Czech Republic) and by using the MALDI-TOF MS biotyper (Bruker Daltonics, Bremen, Germany). Nineteen strains were selected for further testing.

\section{Biofilm formation}

The ability of biofilm formation was assessed in a quantitative assay using a microtiter-plate test (Nunc, Roskilde, Denmark). Strains grown on BHI agar and colonies were re-suspended in BHI broth (Oxoid, UK) to reach the 0.5 suspension McFarland's standard, and volumes of $200 \mu l$ of these cell suspensions were transferred to wells of the microplate. After incubation $\left(24 \mathrm{~h} / 37^{\circ} \mathrm{C}\right)$, adherent cells were washed three times using a saline solution and stained with a $0.1 \%$ crystal violet solution (Mikrochem, Pezinok, Slovakia) for $15 \mathrm{~min}$. Afterwards, excess stain was rinsed off by filling the wells with sterile distilled water. The adhering dye was dissolved with $30 \%$ acetic acid for 15 minutes and the optical density was measured at $570 \mathrm{~nm}$ in Synergy HT Multi-Mode Microplate Reader (BioTek, USA) (Čuvalová, 2018). We divided isolates of $E$. coli into four classes based on Stepanovic et al. 2007. For classification, we used average optical density (OD) value and cut-off value (ODc) (defined as three standard deviations (SD) above the mean OD of the negative control). The final OD value of a tested strain was expressed as the average OD value of the strain reduced by the ODc value. For interpretation of the results, strains were divided into the following categories: $\mathrm{OD}$ $\leq \mathrm{ODc}=$ non-biofilm producer; $\mathrm{ODc}<\mathrm{OD} \leq 2 \times \mathrm{ODc}=$ weak biofilm producer; and, $2 \mathrm{x} \mathrm{ODc}<\mathrm{OD} \leq 4 \times \mathrm{ODc}=$ moderate and $4 \mathrm{x} \mathrm{ODc}<\mathrm{OD}=$ strong biofilm producers.

\section{Detection of genes by PCR} Screening of $E$. coli isolates for APEC virulence genes were carried out by polymerase chain reactions with the amplification of the following: the receptor for aerobactin iutA (Johnson, Stell, 2000); colicin V - cvaC (Johnson, Stell, 2000); increased serum survival - iss (Foley et al., 2000); temperature sensitive haemagglutinin - tsh (Dozois et al., 2000); P fimbrial adhesion - papC (Le Bouguénec et al., 1992); capsular polysialic acid virulence factor - $k p s$ (Johnson, Stell, 2000); iron-regulated gene a homologue adhesion - Iha (Johnson et al., 2000) and genes of iron metabolism - putative iron transport gene - sitA (Rodrigues-Siek et al., 2005); iron-related genes - gene which 
mediates ferric iron uptake $f e o B$ (Rodrigues-Siek et al., 2005), encodes an iron-responsive element and putative sideropohore receptor gene - IreA (Russo et al., 2001) and iron repressible gene associated with yersiniabactin synthesis - irp2 (Schubert et al., 1998), yersiniabactin receptor for ferric yersiniabactin uptake - fyuA (Schubert et al., 1998), and the catecholate siderophore receptor gene - IroN (Johnson, Stell, 2000), and primers are listed in table 1.

Tab. 1. Primers used for detection of virulence genes and genes of iron metabolism

\begin{tabular}{|c|c|c|c|}
\hline Gene & Primer sequences $\left(5^{\prime}-3^{\prime}\right)$ & Annealing $\left[{ }^{\circ} \mathrm{C}\right]$ & Size $[b p]$ \\
\hline iutA & $\begin{array}{l}\text { F: GGCTGGACATGGGAACTGG } \\
\text { R: CGTCGGGAACGGGTAGAATCG }\end{array}$ & 63 & 300 \\
\hline $\mathrm{cvaC}$ & $\begin{array}{l}\text { F: CACACACAAACGGGAGCTGTT } \\
\text { R: CACACACAAACGGGAGCTGTT }\end{array}$ & 63 & 680 \\
\hline iss & $\begin{array}{l}\text { F: ATCACATAGGATTCTGCCG } \\
\text { R: ACAAAAAGTTCTATCGCTTCC }\end{array}$ & 61 & 700 \\
\hline tsh & $\begin{array}{l}\text { F: GGTGGTGCACTGGAGTGG } \\
\text { R: AGTCCAGCGTGATAGTGG }\end{array}$ & 55 & 620 \\
\hline papC & $\begin{array}{l}\text { F: GACGGCTGTACTGCAGGGTGTGGCG } \\
\text { R: ATATCCTTTCTGCAGGGATGCAATA }\end{array}$ & 61 & 328 \\
\hline kps & $\begin{array}{l}\text { F: GCGCATTTGCTGATCGTTG } \\
\text { R: CATCCAGACGATAAGCATGAGCA }\end{array}$ & 63 & 272 \\
\hline Iha & $\begin{array}{l}\text { F: CTGGCGGAGGCTCTGAGATCA } \\
\text { R: TCCTTAAGCTCCCGCGGCTGA }\end{array}$ & 60 & 827 \\
\hline sitA & $\begin{array}{l}\text { F: AGGGGGCACAACTGATTCTCG } \\
\text { R: TACCGGGCCGTTTTCTGTGC }\end{array}$ & 59 & 608 \\
\hline feoB & $\begin{array}{l}\text { F: AATTGGCGTGCATGAAGATAACTG } \\
\text { R: AGCTGGCGACCTGATAGAACAATG }\end{array}$ & 59 & 470 \\
\hline IreA & $\begin{array}{l}\text { F: TGGTCTTCAGCTATATGG } \\
\text { R: ATCTATGATTGTGTTGGT }\end{array}$ & 55 & 415 \\
\hline $\operatorname{irp} 2$ & $\begin{array}{l}\text { F: AAGGATTCGCGTGAC } \\
\text { R: TCGTCGGGCAGCGTTTCTTCT }\end{array}$ & 59 & 287 \\
\hline fyuA & $\begin{array}{l}\text { F: TGATTAACCCCGCGACGGGAA } \\
\text { R: CGCAGTAGGCACGATGTTGTA }\end{array}$ & 55 & 880 \\
\hline IroN & $\begin{array}{l}\text { F:AAGTCAAAGCAGGGGTTGCCCG } \\
\text { R: GACGCCGACATTAAGACGCAG }\end{array}$ & 60 & 655 \\
\hline
\end{tabular}

Results

The interpretation of obtained results requires a definition of the cut-off value that separates biofilm producing from non-biofilm-producing strains. We divided isolates based upon the previously calculated OD values, which was a modification of method and classification described by Stepanović et al. (2007): very weak 12/19 (63.0\% of strains), weak $2 / 19$ (10.5\%), moderate $2 / 19$ (10.5\%) and strong $3 / 19$ (16.0\%) biofilm producers. The occurrences of 13 detected genes are presented in figure 1. Among 19 E. coli isolates, all isolates contained the $f e o B$ gene, 16 isolates contained the sit $A$ 


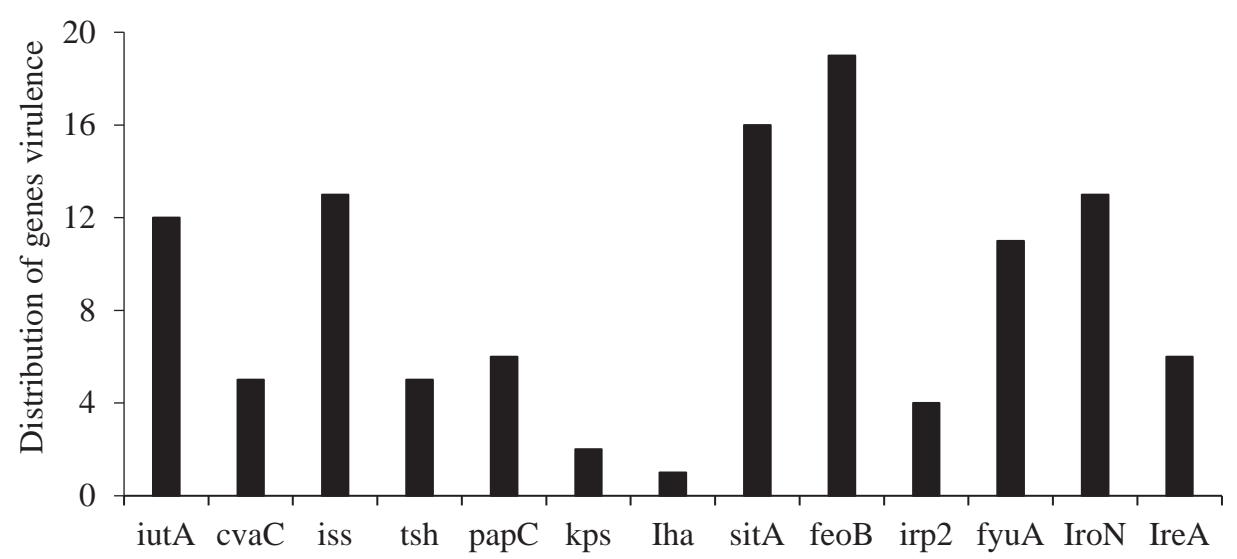

Escherichia coli strains

Fig. 1. Distribution of genes virulence in Escherichia coli strains: iutA (12/19), cvaC (5/19), iss (13/19), tsh (5/19), papC (6/19), kps (2/19), Iha (1/19), sitA (16/19), feoB (19/19), Irp-2 (4/19), fyuA (11/19), IroN $(13 / 19)$ and IreA (6/19)

gene, 13 isolates contained the iss and iroN genes, 12 isolates contained the iutA gene, 11 isolates contained the fyuA gene, 6 isolates contained the papC and IreA genes, 5 isolates contained the $c v a C$ and $t$ sh genes, 4 isolates contained the irp2 gene, and 2 isolates contained the $k p s$ gene.

For better comparison of our results, we created two groups of strains (Fig. 2). The first of the two groups represented very weak biofilm producers and the second group represented weak, moderate, and strong formers. Representation genes of virulence were high in isolates from the first group - from seven genes were six highly, only $p a p C$ was low. Genes of iron metabolism were different. Genes sitA, fyuA, and ireA were higher in the second group, and $f e o B, i r p 2$ and $i r o N$ were higher in the first group.

\section{Discussion}

Genes coding adhesins, toxins, or iron acquisition systems have been described to be of particular importance during the pathogenesis of septicemia (Gyles, 1994; Babai et al., 1997; Terlizzi et al., 2017; Robinson et al., 2018), and iron acquisition is a requirement for UPEC survival in an environment that is as iron-limited as the urinary tract (Skaar, 2010). Isolated E. coli strains were investigated for the presence of thirteen virulence genes that are associated with colibacillosis and iron metabolism.

Two genes, fyuA and irp2, coding proteins involved in iron acquisition, were described in Yersinia sp., and this iron acquisition determinant has been found in human septicemic and enteroaggregative E. coli isolates (Karch et al., 1999; Pelludat et al., 1998; Schubert et al., 1998). The sequences of the irp2 and fyuA genes in E. coli are al- 


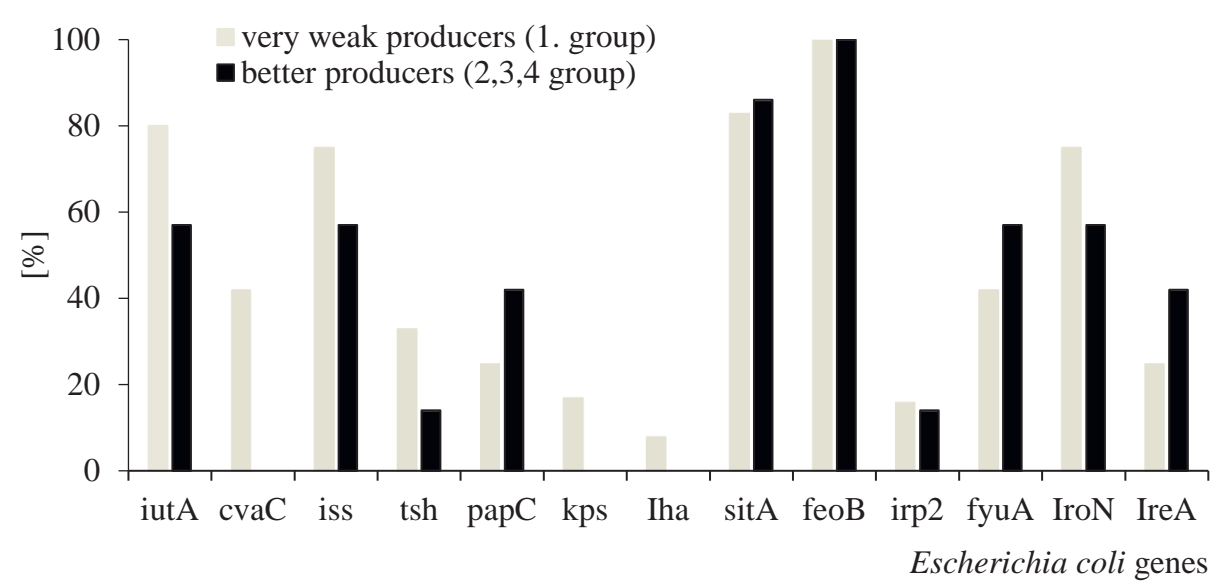

Fig. 2. Presence of detected genes expressed as a percentage; divided in two groups: first group $=$ first column of data (very weak producers) and second group = second column of data (weak, moderate and strong biofilm producers)

most identical to those of Yersinia spp. (Germon et al., 2005) and have been described in APEC isolates by Gophna et al. (2001), Subedi et al. (2018). From nineteen isolates in our study, we detected irp-2 gene in four and fyuA in eleven strains. To increase survival and resistance, E. coli strains also form biofilm, but published data is variable, depending on the strain origin, different types of surfaces, culture medium, and the methodology used for quantifying biofilm. In our study, the presence of genes of virulence was low in second group - better biofilm formers and only papC was higher. To compare with another study (Naves et al., 2008; Pavlickova et al., 2017), papC was also determined in a strain with better forming biofilm, and tsh, which was similar to our results, was detected in weak biofilm formers. IutA was represented in both groups of strains with weak and strong production of biofilm. Genes of iron metabolism shows that $s i t A$, fyuA, and ire $A$ were represented higher in the second group (weak, moderate and strong). Naves et al. (2008) recorded the presence of fyuA in all strong biofilm producers, but iroN, unlike our study, was higher in low biofilm producers. The literature contains only a few papers correlating the virulence factors investigated in this study with the ability of pathogenic E. coli to form biofilms in vitro. Further studies involving larger numbers of clinical strains are needed to corroborate our data concerning the interaction between biofilm formation and virulence factors.

Conclusion

Biofilms are of particular interest in the poultry industry and public health, because these films can harbour pathogenic microorganisms. In this study, Escherichia coli strains were identified and analysed for the presence of genes of iron metabolism, 
virulence-associated genes, and biofilm-forming abilities. All 19 E. coli strains evaluated were able to form biofilms, with the majority exhibiting very weak biofilm-forming potential. The prevalence of the virulence-related genes was higher in low biofilm producers, where the presence of the siderophore-related genes was variable, but no significant differences were observed between strong and weak biofilm producers. Results provide a basis for the further study of the pathogenesis of APEC and its abilities of formation biofilms.

This study was supported by the Slovak project VEGA 2/0085/18.

\section{Acknowledgement}

\section{References}

Babai, R., Blum-Oehler, G., Stern, B.E., Hacker, J., Ron, E.Z. (1997). Virulence patterns from septicemic Escherichia coli O78 strains. FEMS Microbiology Letters, 149, 99-105. DOI: 10.1111/j.15746968.1997.tb10315.x

Čuvalová, A., Kmet', V. (2018). Inhibition of Staphylococcus aureus biofilm by Lactobacillus supernatant and plant extracts. Journal of Food and Nutrition Research, 57(1), 70-75.

Dho-Moulin, M., Fairbrother, J.M. (1999). Avian pathogenic Escherichia coli (APEC). Veterinary Research, 30(2-3), 299-316.

Dozois, C.M., Dho-Moulin, M., Brée, A., Fairbrother, J.M., Desautels, C., Curtiss III., R. (2000). Relation between the Tsh autotransporter and pathogenicity of avian Escherichia coli and localization and analysis of the tsh genetic region. Infection and Immunity, 68(7), 4145-4154.

Foley, S.L., Home, S.M., Giddings, C.W., Robinson, M., Nolan, L.K. (2000). Iss from a virulent avian Escherichia coli. Avian Diseases, 44(1), 185-191.

Germon, P., Chen, Y.H., He, L., Blanco, J.E., Bree, A., Huang, S.H., Moulin-Schouleur, M. (2005). ibeA, a virulence factor of avian pathogenic Escherichia coli. Microbiology, 151(4), 1179-1186. DOI: 10.1099/ mic.0.27809-0

Gophna, U., Oelschlaeger, T.A., Hacker, J., Ron, E.Z. (2001). Yersinia HPI in septicemic Escherichia coli strains isolated from diverse hosts. FEMS Microbiology Letters, 196, 57-60. DOI: 10.1111/j.15746968.2001.tb10540.x

Gyles, C.L. (1994). Escherichia coli in domestic animals and humans. UK, Wallingford: CAB International, Oxon OX10 8DE.

Hannan, T.J., Totsika, M., Mansfield, K.J., Moore, K.H., Schembri, M.A., Hultgren, S.J. (2012). Hostpathogen checkpoints and population bottlenecks in persistent and intracellular uropathogenic Escherichia coli bladder infection. FEMS Microbiol Reviews, 36, 616-648. DOI: 10.1111/j.15746976.2012.00339.x.

Johnson, J.R., Kuskowski, M.A., Smith, K., O’Bryan, T.T., Tatini, S. (2005). Antimicrobial-resistant and extraintestinal pathogenic Escherichia coli in retail foods. The Journal of Infectious Diseases, 191, 1040-1049. DOI: $10.1086 / 428451$

Johnson, J.R., Stell, A.L. (2000). Extended virulence genotypes of Escherichia coli strains from patients with urosepsis in relation to phylogeny and host compromise. Journal of Infectious Diseases, 181(1), 261-272. DOI: $10.1086 / 315217$

Kaper, J.B., Nataro, J.P., Mobley, H.L. (2004). Pathogenic Escherichia coli. Nature Reviews Microbiology, 2, 123-140. DOI: $10.1038 /$ nrmicro818 
Karch, H., Schubert, S., Zhang, D., Zhang, W., Schmidt, H., Ölschläger, T., Hacker, J. (1999). A genomic island, termed high- pathogenicity island, is present in certain non-O157 Shiga toxin-producing Escherichia coli clonal lineages. Infection and Immunity, 67, 5994-6001.

Koo, H., Allan, R.N., Howlin, R.P., Stoodley, P., Hall-Stoodley, L. (2017). Targeting microbial biofilms: current and prospective therapeutic strategies. Nature Reviews Microbiology, 15, 740-755. DOI: 10.1038/nrmicro.2017.99

Kumagai, Y., Matsuo, J., Cheng, Z., Hayakawa, Y., Rikihisa, Y. (2011). Cyclic dimeric GMP signaling regulates intracellular aggregation, sessility, and growth of Ehrlichia chaffeensis. Infect and Immunnity, 79, 3905-3912. DOI: 10.1128/IAI.05320-11

Labbate, M., Queck, S.Y., Koh, K.S., Rice, S.A., Givskov, M., Kjelleberg, S. (2004). Quorum-sensing-controlled biofilm development in Serratia liquefactions MG1. Journal of Bacteriology, 186(3), 692-698.

Le Bouguénec, C., Archambaud, M., Labigne, A. (1992). Rapid and specific detection of the pap, afa, and sfa adhesin-encoding operons in uropathogenic Escherichia coli strains by polymerase chain reaction. Journal of Clinical Microbiology, 30(5), 1189-1193.

Mah, T.F., O'Toole, G.A. (2001). Mechanisms of biofilm resistance to antimicrobial agents. Trends in Microbiology, 9(1), 34-39.

Moulin-Schouleur, M., Schouler, C., Tailliez, P., Kao, M.R., Bree, A., Germon, P., Oswald, E., Mainil, J., Blanco, M., Blanco, J. (2006). Common virulence factors and genetic relationships between O18:K1:H7 Escherichia coli isolates of human and avian origin. Journal of Clinical Microbiology, (44), 3484-3492. DOI: 10.1128/JCM.00548-06

Naves, P., Prado, G., Huelves, L., Gracia, M., Ruiz, V., Blanco, J., Dahbi, G., Blanco, M., Ponte, M.C., Soriano, F. (2008). Correlation between virulence factors and in vitro biofilm formation by Escherichia coli strains. Microbial Pathogenesis, 45(2), 86-91. DOI: 10.1016/j.micpath.2008.03.003

Navidinia, M., Teymouri, A.R., Goudarzi, M. (2018). Assessment of correlation between urinary secretory IgA (sIgA) levels and different types of urinary tract infection (UTI) in various age groups. Journal of Paramedical Sciences, 9, 51-55.

Pavlickova, S., Klancnik, A., Dolezalova, M., Mozina, S.S., Holko, I. (2017). Antibiotic resistance, virulence factors and biofilm formation ability in Escherichia coli strains isolated from chicken meat and wildlife in the Czech Republic. Journal of Environmental Science and Health, Part B, 1-7. DOI: $10.1080 / 03601234.2017 .1318637$

Peerayeh, S.N., Navidinia, M., Fallah, F., Bakhshi, B., Jamali, J. (2018). Pathogenicity determinants and epidemiology of uropathogenic E. coli (UPEC) strains isolated from children with urinary tract infection (UTI) to define distinct pathotypes. Biomedical Research, 29(10), 2035-2043. DOI: 10.4066/ biomedicalresearch.29-17-1591

Pelludat, C., Rakin, A., Jacobi, C.A., Schubert, S., Heese-mann, J. (1998). The yersiniabactin biosynthetic gene cluster of Yersinia enterocolitica: organization and siderophore-dependent regulation. Journal of Bacteriology, 180, 538-546.

Robinson, A.E., Heffernan, J.R., Henderson, J.P. (2018). The iron hand of uropathogenic Escherichia coli: the role of transition metal control in virulence. Future Microbiology, 13(7), 745-756. DOI: 10.2217/ fmb-2017-0295

Rodriguez-Siek, K.E., Giddings, C.W., Doetkott, C. (2005). Comparison of Escherichia coli isolates implicated in human urinary tract infection and avian colibacillosis. Microbiology, 151, 2097-2110. DOI: 10.1099/mic.0.27499-0

Ron, E.Z. (2006). Host specificity of septicemic Escherichia coli: human and avian pathogens. Current Opinion in Microbiology, 9, 28-32. 
Russo, T.A, Ulrike, B., Carlino, U.B, Johnson, J.R. (2001). Identification of a new iron-regulated virulence gene, ireA, in an extraintestinal pathogenic isolate of Escherichia coli. Infection and Immunity, 10, 6209-6216. DOI: 10.1128/IAI.69.10.6209-6216.2001

Schubert, S., Rakin, A., Karch, H., Carniel, E., Heesemann, J. (1998). Prevalence of the "high-pathogenicity island" of Yersinia species among Escherichia coli strains that are pathogenic to humans. Infection and Immunity, 66(2), 480-485.

Skaar, E.P. (2010). The battle for iron between bacterial pathogens and their vertebrate hosts. PLoS Pathogeny 6(8), e1000949. DOI: 10.1371/journal.ppat.1000949

Stepanović, S., Vuković, D., Hola, V., Di Bonaventura, G., Djukić, S., Cirković, I., Ruzicka, F. (2007). Quantification of biofilm in microtiter plates: overview of testing conditions and practical recommendations for assessment of biofilm production by Staphylococci. Journal of Pathology, Microbiology and Immunology, 115, 891-899. DOI: 10.1111/j.1600-0463.2007.apm_630.x

Subedi, M., Bhattarai, R.K., Devkota, B., Phuyal, S., Luitel, H. (2018). Correction to: Antibiotic resistance pattern and virulence genes content in avian pathogenic Escherichia coli (APEC) from broiler chickens in Chitwan, Nepal. BMC Veterinary Research, 14(1), 166. DOI: 10.1186/s12917-018-1453-9

Terlizzi, M.E., Gribaudo, G., Maffei, M.E. (2017). UroPathogenic Escherichia coli (UPEC) infections: virulence factors, bladder responses, antibiotic, and non-antibiotic antimicrobial strategies. Front Microbiology, 8, 1566. DOI: 10.3389/fmicb.2017.01566

Tu, J., Xue, T., Qi, K., Shao, Y., Huang, B. (2016). The irp2 and fyuA genes in High Pathogenicity Islands are involved in the pathogenesis of infections caused by avian pathogenic Escherichia coli (APEC). Polish Journal of Veterinary Sciences, 19(1), 21-29. DOI: 10.1515/pjvs-2016-0004

Vasudevan, R. (2014). Biofilms: microbial cities of scientific significance. Journal of Microbiology Experimental, 1-14. DOI: 10.15406/jmen.2014.01.00014

Wang, Y., Jayan, G., Patwardhan, D., Phillips, K.S. (2017). Antimicrobial and Anti-Biofilm Medical Devices: Public Health and Regulatory Science Challenges. In: Z. Zhang, V. Wagner (eds.), Antimicrobial Coatings and Modifications on Medical Devices. Springer, Cham. DOI: 10.1007/978-3-319-57494-3_2

\section{Abstract}

Escherichia coli is known as one of the bacterial species with the widest adaptability to a variety of niches either within organisms or outside in environment. Most strains of $E$. coli are of low virulence and associated with opportunistic infections, whereas others are highly virulent. The success of $E$. coli in colonising such a wide range of hosts and environments is basically due to a noticeable ductility in exploiting the available resources. It is becoming increasingly clear that biofilms have an enormous impact on medicine, because $65 \%$ of animal and human bacterial infections involve biofilms. In the present study, we isolated strains of E. coli from animals. 19 interesting isolates were selected and tested by PCR amplification to virulence iut $A, c v a C$, iss, tsh, papC, $k p s$, iha and iron metabolism genes - sitA, feoB, irp2, fyuA, iroN, and ireA. The ability of biofilm formation was assessed in a quantitative assay using microtiter-plate tests. Bacterial strains were grown on BHI. We divided isolates of $E$. coli into four classes: very weak (63.0\%), weak (10.5\%), moderate (10.5\%), and strong (16.0\%) biofilm producers. Representation genes of virulence were high in isolates from very weak biofilm producers - from 7 genes were 6 highly and only papC ( $\mathrm{P}$ fimbrial adhesin) was low. Genes of iron metabolism were different. Genes - sitA, fyuA, and ire $A$ in strong isolates producing biofilm and $f e o B$, irp2, and iroN in weak producers were most represented. The results show a possible relation between presence virulence factors and low biofilm formation.

Key words: biofilm, virulence genes, iron metabolisms genes

Received: [2018.05.30]

Accepted: [2018.12.29] 


\section{Związek pomiędzy tworzeniem się biofilmu, genami wirulencji i metabolizmem żelaza u Escherichia coli}

Streszczenie

Escherichia coli znana jest jako jeden z gatunków bakterii o najszerszej zdolności adaptacji do różnych nisz w organizmach lub w środowisku zewnętrznym. Większość szczepów E. coli ma niską wirulencję i wiąże się z infekcjami oportunistycznymi, podczas gdy pozostałe szczepy są wysoce wirulentne. Sukces E. coli w kolonizowaniu tak szerokiego zakresu żywicieli i środowisk wynika przede wszystkim z zauważalnej ciągliwości w wykorzystywaniu dostępnych zasobów. Staje się jasne, że biofilmy mają ogromny wpływ na medycynę, ponieważ $65 \%$ zakażeń bakteryjnych zwierząt i ludzi dotyczy biofilmów. W obecnych badaniach izolowano szczepy E. coli ze zwierząt. Wybrano 19 interesujących izolatów i testowano je przez amplifikację PCR pod względem wirulencji - geny metabolizmu iut $A, c v a C$, iss, tsh, papC, $k p s$, iha oraz żelaza - sit A, feoB, irp2, $f y u A$, iroN, ireA. Zdolność tworzenia biofilmu oceniano w teście ilościowym, stosując test płytki mikrotitracyjnej. Szczepy bakteryjne hodowano na BHI. Izolaty E. coli podzielono na cztery klasy producentów biofilmu: bardzo słabe $(63,0 \%)$, słabe (10,5\%), umiarkowane (10,5\%) i silne (16,0\%). Geny reprezentacyjne wirulencji były w większości izolowane od bardzo słabych producentów biofilmu - z 7 genów było 6 wysoko wirulentnych; tylko papC (adhezyna fimbrialna) była niska. Geny metabolizmu żelaza były różne pod względem wirulencji. Najbardziej reprezentowane były geny - sitA, fyuA, ire $A$ w silnych izolatach produkujących biofilm oraz $f e o B$, irp2, iroN u słabych producentów. Wyniki pokazują możliwą zależność pomiędzy obecnym czynnikiem zjadliwości, a niską formacją biofilmu.

Słowa kluczowe: biofilm, geny wirulencji, geny metabolizmu żelaza

\section{Information on the authors}

Lívia Handrová http://orcid.org/0000-0002-0985-1771

The main area of her interest is genetic ecology and the spread of antibiotic resistance genes. She studies the resistance occurrence in small mammals, which could serve as a reservoir of antibiotic resistance (ESBL, plasmid encoded chinolone resistance, carbapenemases) in indicator bacteria Escherichia coli, Pseudomonas aeruginosa and Staphylococcus spp.

\section{Anna Čuvalová}

She is interested in anti-biofilm activities of natural compounds using the static and dynamic biofilm models with resistant staphylococci (MRSA and MRCoNS), Escherichia coli (ESBL and cefotaximases) and Pseudomonas aeruginosa on various surfaces (plastics, catheters and food grade stainless sheet).

Vladimír Kmet' http://orcid.org/0000-0002-8081-8579

He is interested in biofilm and anti-biofilm activities of natural compounds using the static and dynamic biofilm models with Escherichia coli, resistant staphylococci (MRSA and MRCoNS). The area of his interest is genetic ecology and gene encoding factors of virulence, metabolism, and the spreading of these genes. He studies the resistance occurrence in animal, which could serve as a reservoir of antibiotic resistance in indicator bacteria. 